\title{
Failed technology futures: pitfalls and lessons from a historical survey
}

\author{
Frank W. Geels *, Wim A. Smit \\ Dept. of Philosophy of Science and Technology, University of Twente, TWRC Room D-304, PO Box \\ 217, 7500 AE Enschede, The Netherlands
}

\begin{abstract}
Images of the future, with hindsight, turn out to be either right or wrong. In this article, past images of the impact of Information and Communication Technology (ICT) on traffic and transportation are investigated. Informed by the field of technology studies, seven key features are formulated that point at pitfalls and neglected aspects in many future expectations on technological developments and their societal impact. It is also argued that the evolution from broad sweeping promises to more down-to-earth assessments is inherent in technological developments, because expectations and diffuse scenarios also play a performative role in technological developments. (C) 2000 Elsevier Science Ltd. All rights reserved.
\end{abstract}

\section{Introduction}

History abounds with future images, speculations, scenarios and so on, of how new technologies will transform society. In retrospect, they often turn out to be wrong. In this article we analyse why many images about technology futures were wrong, using insights from the field of technology studies. On the basis of this analysis, we draw lessons and provide key features, for improving technology scenarios. Without claiming a priori knowledge about the future, future scenarios may be improved by taking into account insights about important interactions between technology and society.

We have empirically investigated the past evolution of the predicted impact of information and communication technology (ICT) on traffic and transportation.

\footnotetext{
* Corresponding author. Tel.: +31-53-489-3350; fax: +31-53-489-4775. Smit)

E-mail addresses: f.w.geels@wmw.utwente.nl (F.W. Geels), w.a.smit@wmw.utwente.nl (W.A.
} 
Speculations on this domain range back to the introduction of the telephone. Given this long history, future images in this domain lend themselves to a longitudinal analysis. Moreover, many past images of the future in this domain have not materialised, and last but not least, the choice of this domain has practical relevance, as many Ministries of Transportation have high expectations of ICTs to alleviate, if not solve, transportation problems like congestion, air pollution and energy use.

This article is organised as follows. First, we give a categorisation of types of impact of ICT on traffic and transportation. This categorisation is then used to present the findings from a longitudinal survey of shifts that occurred in the future expectations of the impact of ICT on traffic and transportation [1,2]. Several descriptive methods are used, ranging from literal quotations to overview tables of quantitative estimations. We do not aim at presenting all past images nor do we strive for a complete description of them. Instead, we will give sufficient descriptive material for an interesting analysis that leads to an answer to the question why many past images of the future have failed.

Using insights from technology studies, we distil a number of recurring key features in conceptualisations or ways of thinking that may cause future images to fail. We then translate these key features into more general lessons and pitfalls for future speculations about the development and impact of technology. The lessons and pitfalls focus, in particular, on the (implicit) conceptualisations of how technology develops and shapes society. In the penultimate section a complementary interpretation of one of the key features will be given, which focuses on the performative role of expectations in technological developments. The article ends with some concluding remarks.

\section{A categorisation of impacts of ICT on traffic and transportation}

Speculations on the impact of information and telecommunication technology (ICT) on traffic and transportation range back to the introduction of the telephone more than a century ago. The telephone's gradual introduction was accompanied by vehement discussions about its impact on social life. Although transportation itself was not so much an issue in these discussions, some people expressed their fear that future generations might remain indoors, maintaining necessary contacts only via the telephone. Fischer [3] quotes the following future image from 1893, describing life in 1993:

Families would live on scattered homesteads, neighboured only by people of like sentiment and quality, would conduct their work electronically, and would meet each other only at ceremonial occasions (p. 224).

Thus, the current idea of an "electronic cottage" is not as new as it may seem. Another early example that will be discussed later are speculations about automated cars and highways which were already around in the 1930s.

In order to present a more systematic description in the next section we have made 
a distinction between two types of impact of ICT on transportation. Direct impacts refer to the implementation of information technologies in the transportation system itself. Indirect impacts refer to the use of information technology in business (e.g. working at distance from the office) or otherwise, that have a spin-off effect on transportation. Table 1 gives some examples and preliminary indications about the time of their popularity.

\section{A longitudinal description of past expectations of the future}

In our selection of past images of the direct impact of ICT on transportation we distinguish three periods. The first period is the second half of the 1930s, the second is from the mid-1960s to the 1970s, and the third period starts in the mid-1980s.

Regarding the indirect impact of ICT we focus on three areas of impact: teleconferencing, substitution of goods, and tele-working. The empirical descriptions in this section provide the material that will be analysed in the next section, in order to find reasons for the failure of future speculations.

\subsection{Direct impacts}

The first period dates back to the second half of the 1930s and consists of sweeping speculations about automatic cars and road systems. General Motors in particular,

Table 1

Some direct and indirect impacts of ICT on traffic and transportation

Impact of ICT on traffic and transportation

Direct impact

*Steering systems

*Informative systems

Indirect impact

*Substitution of physical goods

*Teleconferencing

*Tele-working (-commuting)
Brief description

Guidance of cars using computers;

- "feet off": computer controls gas pedal and velocity [popular in mid-1980s];

— "hands off": computer and sensors steer the car in a limited fashion;

— "brains off": computer steers the car to given destination [popular in late 1930s, mid-1960s and 1970s]

Board computer receives relevant information via traffic telematic systems, processes it and provides suggestions to driver. Driver uses information for decisions (e.g. about alternative routes or transport modes). [popular from mid-1980s]

Certain material flows (e.g. paper, news papers) are replaced by computers and telematics. [popular in mid-1960s and 1970s]

Communication via image-telephone or computer substitutes for business travel. [popular in mid-1960s and 1970s]

People work on computer systems outside the office (e.g. at home), thus reducing commuter traffic. [popular in 1970s and 1980s] 
most spectacularly articulated these future images at the World Fair of 1939 in New York. In its Futurama exhibition GM toured visitors around through scale models, demonstrations and films, showing a future transportation system where almost everything would operate automatically. After people had pushed the buttons of their vehicle, and instructed its destination, an automatic electronic system, and roads with invisible rails and radar systems would take them there.

The second period ranges from the second half of 1960s through the 1970s. The dominant characteristic of many expectations from that period is the role of the computer as a central planning and steering device. A number of nice illustrations of this way of thinking can be found in the book "The world in 1984: The complete New Scientist series", edited by Nigel Calder [4]. Scientists and engineers were invited to express their future images. Bournonville, for instance, an engineer at the Compagnie des Machines in Paris, expected that "twenty years from now, a machine may be used to direct traffic for a large city" [5:140], and Glanville [6], director of the Roads Research Department of Scientific and Industrial Research, wrote:

By automatic control of large numbers of detectors and traffic signals, the computer will be continuously assessing the traffic position over an area and organising it to obtain the most efficient flow. (p. 189).

This would result in a 50\% increase in road capacity, average speed and a decrease in casualties. Illustrations can also be found in other countries, for instance The Netherlands. In a publication by the Foundation of Future Images of Technology (STT), Professor Van der Burgt [7] expresses as his vision that a central computer would take care of the speed, direction and integration of cars in smooth traffic flows. The road capacity could thus be increased by $100 \%$, and in "Transport in the Future", a book edited by the Dutch transportation expert Hupkes [8], many types of automated city traffic systems were described. Hupkes himself describes a complex system of rails with many stops on which small cabins move around, which react to the travellers who can push the buttons. The cabins' movements are based on electronic systems, and a large central computer does the steering.

The third period starts in the mid-1980s, when the technological areas of telecommunication, mass-communication, data-communication and data-processing start to overlap, constituting the new field of telematics. From then on speculations about traffic telematics emerge. Initially, the speculations often relate to partial applications, and gradually they focus more on an integrated system including: i) information collection (by sensors, satellites, cameras), ii) information processing (a central computer aggregating and integrating incoming partial messages) and iii) information transmission (via beacons next to the roads to board computers in cars).

Although the theme from the second period, that is automated vehicle guidance, remains alive, the emphasis in many future expectations has shifted to informative systems (see Table 1). The general claim in many of these expectations is that traffic telematics will substantially improve the efficiency of the transportation system. Next to an increase in transportation comfort (e.g. better planning of routes, avoiding 
traffic jams), reduced traffic congestion, improved safety and reduced pollution are expected.

On the basis of these optimistic expectations many private and governmental R\&D projects on transport telematics have been started. For instance, in 1986, the multinational electronics company Philips started developing the CARIN-system (CAR Information and Navigation). ${ }^{1}$ This system uses an on-board computer in the car, a positioning system and a special digital radio. The project leader Thoone [9] expressed the expectation that the wide application of traffic telematic systems might improve road efficiency by $20 \%$. A similar estimation can be found in the Dutch Ministry of Transportation's first White Paper about Telematics, Traffic and Transportation [10], where it is stated that:

[i]t is thought that road capacity may be increased by $30 \%$ with the help of telematics (p. 19).

Despite all these optimistic promises, there are also critics who point at the many uncertainties that are still ahead. For instance, the high costs of integrating electronic devices in the existing infrastructure may be a problem. Also the efficiency gains in congestion and environmental emissions are still highly uncertain, especially when congestion occurs on roads for which there is no alternative [11]. After some years of working on the implementation of traffic telematics, the second and third White Papers by the Dutch Department of Transportation, Telematics, Traffic and Transportation [12] and Progress Evaluation Telematics, Traffic and Transportation 19931995 [13], are much less optimistic about quick and smooth introduction of traffic telematics. The second White Paper argues for a necessary shift from technologypush to a more demand oriented approach, referring to the limited absorptive capacity of users, the slowness in the emergence of co-operation between suppliers, the organisational bottlenecks in introducing the technology, and the high costs. It also mentions that the initial expectations were too high. The third White Paper no longer mentions quantitative expectations or objectives. Instead it talks about process goals, like contacts, networks, consultations, alliances, the realisation of which took much more time than was expected.

Comparing the second and third period, we stress three points. In contrast to the second period, the emphasis in the third period has been on decentralisation, providing supportive information to independent car drivers that have to make decisions themselves. Although central aggregation and processing of information do occur, the central role is for the decentralised board computers in individual cars. Traffic problems are no longer dealt with by centrally organised and (bureaucratically) con-

\footnotetext{
${ }^{1}$ Other programmes are: 1) The Intelligent Vehicle Highway Systems (IVHS) in the USA. Federal support amounted to $\$ 25$ million in $1991 / 92$ and $\$ 600$ million for the five year period 1992-1996; 2) Japan is leading in transport telematics. Since 1992 the ATIS-system (Automatic Transportation Information System) is for sale. It has become popular very fast and at the end of 1994 about 500,000 copies have been sold; 3) Europe stimulates co-operation between governments, car- and electronics industry with large scale R\&D projects, e.g. PROMETHEUS, DRIVE I, DRIVE II
} 
trolled systems and large computers, but by providing citizens with sufficient information in order to enable them to make the right decisions. In a publication by the privately funded Foundation for Society and Enterprise [14], entitled "Traffic chaos and transportation hunger: A perspective on mobility", Professor Bovy formulates it as follows (p. 35-36):

Decisions about the guidance of the optimal use of place and time are no matter for super traffic control centres. The intelligence is situated mainly low in the system, at the level of individual users. They themselves can best make decisions about optimal routes and times on the basis of up to date information about present and to be expected traffic circumstances [our translation, FWG and WAS].

Second, when governments and firms embarked on implementing telematics into the traffic system, they were confronted with practical difficulties that had not been mentioned in the earlier and broad speculations. The societal embedding process of the technology went much slower than was expected.

Third, compared to the second period, expectations for improvements of road efficiency have decreased in the third period. Table 2 summarises some findings.

\subsection{Indirect impacts}

Below we will discuss three areas of the "information society" or "tele-world" which have been expected to have an (indirect) impact on transportation: tele-conferencing, substitution of goods, and tele-working.

Visions about widespread tele-conferencing became popular in the 1960s, when speculations about a technological fusion between telecommunication, data-communication and television emerged. Of course, the telephone has always been a technology to facilitate some sort of tele-conferencing between two persons, but now the issue was to have real-time business meetings in which many persons participated that were scattered over the world. Again, "The world in 1984" edited by Calder [4], provides some illuminating examples. According to Barry [15] associated with the Granada TV network, the need for business travel will decline, because "the simple device of telephone-plus-television will often make the fastest journey seem

Table 2

Estimations on the direct impact of ICT on road efficiency

\begin{tabular}{ll}
\hline Reference & Estimation of increased road efficiency \\
\hline Glanville in 1964 [6] & $50 \%$ \\
Van der Burgt in 1968 [7] & $100 \%$ \\
Thoone in 1987 [9] & $20 \%$ \\
First White Paper Telematics, Traffic and & $30 \%$ \\
Transportation in 1990 [10] & Increased attention for practical problems of \\
1990s literature [11-14] & societal embedding; decreased efficiency estimates \\
\hline
\end{tabular}


unnecessary" (p. 159), and Pierce [16], researcher at Bell Telephone Laboratories, states:

I see by 1984 greatly extended data communication and improved telecommunication as a substitute for travel (p. 153).

Clare [17], a researcher at Standard Telecommunication Laboratories, not only articulates a vision, but also points the direction that technological development should take:

In order to remove the need for the majority of the personal contacts at present necessary in most business operations and to provide the facilities that obviate gatherings at conferences, telecommunications must provide a form of high-definition colour television associated with high quality audio-channels: every blush and nuance needs to be accurately conveyed (p. 155).

The examples show that tele-conferencing is often linked with the promise of a reduction of business travel. The idea that it actually substitutes for business travel is based on the assumption that business processes require a fixed and static number of social contacts: an increase in tele-conferencing, therefore, would automatically lead to a reduction of travelling. Thus, the possibility that tele-conferencing might add an extra mode of social contact, that would increase the total number of contacts was not considered.

Though the substitution potential of tele-conferencing figures in many images since the 1960s, there are only a few quantitative estimates of the effect (see also Table 3).

A second area for which indirect effects of the emerging information society on transportation has been predicted, is the replacement of physical goods. Especially paper products (e.g. newspapers, letters, books, library, mail) were expected to be substituted by electronic devices and computer systems. Although the so-called "paperless society" has rarely explicitly been connected with solving transportation problems, we include this effect because it clearly illustrates the strength of the substi-

Table 3

Estimations of substitution potential of tele-conferencing

\begin{tabular}{ll}
\hline References & Estimation of substitution potential \\
\hline German estimate from 1974/75 [18] & $\begin{array}{l}66 \% \text { of business travel in Germany } \\
34 \% \text { of internal office meetings in United } \\
\text { Kingdom + an additional 10\% by using video- } \\
\text { systems } \\
\text { Goddard and Morris in 1976 [19] }\end{array}$ \\
$\begin{array}{l}\text { Kraemer in 1982 [20] } \\
\begin{array}{l}\text { European Conference of Ministers of Transport } \\
\text { (ECMT) in 1983 [21] }\end{array}\end{array}$ \\
$\begin{array}{l}\text { Henckel et al. in 1984 [22] } \\
\text { Hess travel }\end{array}$
\end{tabular}


tution idea. Since the image of a future information society emerged in the 1960s, visions about a paperless society have been popular. Computers and terminals would penetrate both work and home practices, replacing paper products. Once again, Nigel Calder's "The world in 1984" [4] illustrates this. Samuel [23] a researcher at the Watson Research Centre in New York, expects that, in 1984, almost everybody would have his/her own computer or terminal and be able to log in on central files where all information would be stored. As a result, "Libraries for books will cease to exist in the more advanced countries" (p. 145). This vision links up with the more general idea at that time that all future information streams would be channelled through computers. Samuel further expects that "all office paperwork will cease to exist in twenty years" (p. 146). Pierce [16], a researcher at Bell Telephone Laboratories, foresees a form of e-mail and thinks this will strongly decrease regular mail:

I expect that most of the sort of business letters which are now sent by airmail, and perhaps most business correspondence, will be sent electronically from machinereadable records (p. 151).

According to Barry [15], associated with the Granada TV network, newspapers and news distribution will change drastically:

Web-offset and gravure methods of printing have set off changes in the newspaper technique that are about to affect radically the whole newspaper economy.(p. 157) In the area of mass-communication it is predictable that, in the long-term, the "newspaper" of the future will be electronic, if indeed it can be called a newspaper in the presently accepted sense at all (p. 158).

Almost two decades later, the idea of substitution of newspapers still reverberates in the popular book Megatrends by futurist Naisbitt [24]:

At a certain point in time some American cities will contain so many computers that local newspapers will decide to stop publishing on the basis of increasingly expensive paper.

As these quotations indicate, many future expectations assume that a new technology substitutes for old technologies. With hindsight, we now know that newspapers, letters, and books exist next to e-mail, data-communication, electronic journals and so on. What is more, taking a look at the printer in our department, one notices that the access to Internet results in the printer pouring out more paper than ever before. Rather than a paperless office, we have got a "printing office". Again, old and new technologies apparently can co-exist.

The third area causing an indirect impact on traffic and transportation is teleworking (or tele-commuting as it is often called in American literature), implying that employees don't work in a central office, but at dispersed places (e.g. their homes). Still, the employees can work together, because they are connected via computers and telecommunication networks. One speculated advantage of tele-working 
is that it could reduce commuter traffic, even if employees would work only part of the time at home.

Actually, some tele-working already existed in practice before it became part of wide ranging future expectations. In the 1960s, several companies practised forms of tele-working to reduce costs and increase flexibility. The software firm F-International (the F standing for "freelance"), for instance, had created a pool of highly educated free-lance employees, to whom it channelled assignments from customers. These employees were paid per task. Another early example is the Dutch National Giro Bank. When its two centres, where hand written parts of cheques had to be encoded for feeding into a computer, were faced with a shortage of labour (mainly young women) the Giro Bank chose a decentralisation strategy. It created a number of geographically dispersed small centres, from which the encoded messages were fed into a large central computer via data communication.

In the 1970s the idea of tele-working became very popular with academics and futurists engaged in speculations on the "post-industrial" and "information society". Rather than a solution to business problems, tele-working now became linked with solving societal problems. After the oil crisis in 1973, for instance, tele-working was suggested as a means to save energy. Studies with a large influence were: The telecommunications-transportation trade-offs: "Options for tomorrow" by Nilles et al. [25] and Technology assessment of telecommunications-transportation interactions, from the Stanford Research Institute [26]. The latter explored different options and described a range of future possibilities, but it is especially the high range estimate, notably that $50 \%$ of all office jobs could be done at home, that later on has most often been referred to. Although the 1970s showed very few empirical studies on tele-working in practice, many speculative publications were referring to each other, thus creating a kind of bandwagon effect.

In the 1980s, speculations about tele-working became even more widespread, in particular through popular works from authors like Toffler [27] and Naisbitt [24]. Toffler coined the term "electronic cottage" in his book "The Third Wave". He estimated the potential of home tele-workers between 35 and 50 percent of the working population in 1990, and points not only to advantages of reduced mobility but also to greater societal stability, less stress, less temporary relationships and greater involvement in community life. In the 1980s academic researchers felt a need to get more grip on the phenomenon of tele-working, which resulted in more quantitative estimations, more empirical research and more conceptual discussions, for instance on the concepts of "information worker" and "tele-working". Still, the many studies use different definitions, making it difficult to compare (see Table 4).

Since the mid-1980s, governments, stimulated by the promised societal advantages of tele-working, have encouraged experiments and have co-operated with companies to this end. Though the number of tele-workers has increased, the growth is much slower than predicted. Becoming engaged in implementation experiments, rather than in wide speculations, governments and companies are confronted with practical and down-to-earth problems. For instance, employees that are willing to try tele-working at home find that their houses lack space to set up an ergonomically acceptable workplace. Employees discover that they miss the informal and social interactions 
Table 4

Some estimations of numbers or percentages of tele-workers

\begin{tabular}{|c|c|}
\hline References & Estimations \\
\hline Stanford Research Institute in 1977 [6] & $\begin{array}{l}50 \% \text { of white collar jobs (in the high range } \\
\text { scenario) }\end{array}$ \\
\hline Toffler in 1980 [27] & $\begin{array}{l}35-50 \% \text { of working population in information } \\
\text { societies }\end{array}$ \\
\hline Magazine "The Futurist" (June 1983) & 10-15 million tele-workers in 1990 in the USA \\
\hline Nilles in 1984 [28] & 20 million tele-workers in 2000 in USA \\
\hline Elecronic Services Unlimited in 1984 [29] & $20 \%$ of working population in 1990 in USA \\
\hline Dutch Organization for Applied Scientific & $50 \%$ of office functions in 2010 in The \\
\hline Research (TNO) in $1984^{\mathrm{a}}$ & Netherlands, for part of the week \\
\hline Nilles in 1985 [31] & 10 million tele-workers in 1990 in USA \\
\hline Miles et al. in 1985 [32] & $\begin{array}{l}10-15 \% \text { of British working population in } 1990 \text {; } \\
15-20 \% \text { in } 2000\end{array}$ \\
\hline Dutch Telecom in $1986^{\mathrm{b}}$ & $\begin{array}{l}600,000-1,800,000 \text { people tele-working part of the } \\
\text { week in } 1995 \text { in The Netherlands (11-34\% of } \\
\text { working population) }\end{array}$ \\
\hline Weijers and Weijers in 1986 [34] & $\begin{array}{l}40,000-80,000 \text { tele-workers in The Netherlands in } \\
\text { near future }(0.8-1.6 \% \text { of working population) }\end{array}$ \\
\hline Meijer et al. in 1992 [35] & $\begin{array}{l}\text { A potential of } 25-37 \% \text { of working population } \\
(1.3-1.92 \text { million people) in The Netherlands for } \\
\text { at least one day a week }\end{array}$ \\
\hline
\end{tabular}

${ }^{a}$ Cited in report from Telematics Research Centre [30]

b Cited in Kok et al. [33]

with their colleagues. The fading distinction between work and private life results in psychological problems in the family. Employees feel that tele-working reduces their career opportunities, as they have less contact with their superiors. On the other hand, managers feel that they have less control over their employees, as the latter are working out of sight.

Thus, it becomes clear that the process of societal embedding of tele-working does not proceed automatically and smoothly. Instead, all kinds of existing practices need to be adjusted and changed. Against this background, critical voices and articles emerge, making the point that earlier future speculations have paid too little attention to bottlenecks in the societal embedding of tele-working [36-38].

Another critique on the earlier promises regarding the advantages of tele-working comes from traffic experts [39-41]. According to these experts the first order effect of substitution of commuter traffic may not be the only effect of tele-working. They point out that traffic should be seen as an integrated whole of several subsystems, for instance regarding recreation, social, commuting and shopping. Changes in one subsystem may go together with opposite changes in another subsystem. Thus, the reduction in commuting traffic may have as a second order effect an increase in recreational or social traffic. Tele-working, therefore, may well have traffic generation effects besides substitution effects. 


\section{Analysis: key features in images of the future role of new technologies}

In this section we distil a number of recurring key features from the historical future expectations described above.

A first key feature is that expectations may be biased by the broader cultural concerns of the time. People's perception of the future is often coloured by their cultural lens. Consequently, future expectations often reflect broad cultural concerns and hopes. This, to some extent, may also explain why certain future images gain widespread popularity.

Thus, the popularity of speculations on automated cars and roads in the second half of the 1930s may be explained partly as a reaction to the first years of the 1930s, which were characterised by world wide economic depression and unemployment. The Futurama-exhibition by General Motors can then be interpreted as a wider cultural promise of a better society through (electronic) technology, a promise for a smoothly functioning society, characterised by abundance and ease. To escape such biases one might design "unlikely" next to more plausible scenarios, similar as the oil company Shell used to do [42,43].

A second key feature is that sudden new trajectories in technological developments may trigger shifts in future images. The emergence of the PC and smaller workstations around 1980 opened up a new technological trajectory, wholly different from the traditional path towards ever-larger main frame computers. It also opened up a new direction of expectations on the impact of computers on car traffic. Whereas in the mid 1960s and the 1970s future images referred to centralised computers that would steer and control traffic systems, these centralised computers lost their central role in the future images since the mid 1980s and gave way to decentralised board computers. Connected with the shift from central to decentralised control, a shift in technology occurred from steering systems to informative systems. Whereas in the "centralised steering system", the driver only needs to type in his destination, and can then sit back while the central computer does the work, in "informative systems", the driver still has to make his own decisions on how to act, but now based on information that he receives from the system.

At the same time, this shift from centralised to decentralised control correlated with similar trends in Zeitgeist, away from the idea that governments could determine societal developments (though we do not suggest a causal linear relationship, or a cultural determinism). The example, therefore, also illustrates the influence of broad cultural trends, i.e. the first key feature mentioned above.

A third key feature is that in speculations about the future, the role of a new technology is often phrased in terms of replacing or substituting the old technology, that is, in terms of winners and losers. In reality, however, old and new technologies often co-exist and service different markets and customer groups. The electronic information storage and transmission technology did not result in the expected "paperless society". By contrast, even more printed paper is being produced: not a "paperless society", but a "printing office" emerged. In addition to a (small) substitution effect, a generation effect is taking place.

One explanation of this thinking in terms of winners and losers, is that initially 
a new technology often is given meaning from existing technological contexts: the first car was called a horseless carriage [44]; initially, the telephone was seen as a special kind of telegraph [3], as was the first radio, sending wireless messages between two points [45]. Therefore, it may easily happen that the new technology is expected to substitute for the old technology.

The reason why people initially interpret the emerging new technology in terms of the old technology is that all the potentials, properties and new meanings of the emerging technology are still to be found out. This occurs in, what has been called the "co-evolution of technology and society" [46], or also the process of "societal embedding" of the technology [47], when learning processes occur in which the technology is further developed, more applications are "discovered", and new meanings are attributed and articulated. So it takes time to struggle out of the grip of the old technology's meaning.

A fourth key feature is the neglect of the generation of new activities by assuming that the pool of existing social practices and needs remains basically unchanged. From this assumption it may seem logical that the new technology will substitute certain social practices. For instance, many of the past expectations and quantitative estimates of the impact of tele-conferencing on business travels implicitly assumed that business processes required a fixed number of social contacts. Consequently, it was expected that the increasing contacts via tele-conferencing would result in a decrease of contacts via business travel. However, we now know that the pool of social practices in business has both been extended and intensified.

The same may be true for the expectations that tele-working would reduce traffic as it would substitute for commuting. While there will be substituting effects, traffic experts have recently pointed out that tele-working might also intensify mobility in different parts of the traffic system, like social and recreational trips. For instance, it is possible that the tele-worker will make more non-commuting trips in the extra "free" time (e.g. see friends, do shopping). Furthermore, other members of the household may use the car when it is not used for commuting trips. Another traffic generating aspect which is often mentioned is that tele-working may contribute to moving house to more distant, "green" locations ("urban sprawl"). The substitution of trips on tele-working days is thus partly offset by longer trips on commuting days.

From this it is clear that there are both substitution and generation effects. Therefore, the fourth key feature has in that respect a similar implication as the third key feature. However, the underlying assumptions revealed by the third and fourth key factors that cause future images to go wrong are different.

A fifth key feature is so-called narrow functional thinking. The expectation has been voiced that the phenomenon of "tele-shopping" or "virtual shopping", via The Internet, would substitute for physical shopping, thus reducing the need for traffic. Such future images view the social activity of shopping as a purely functional activity of purchasing required goods. Such purely functional thinking neglects other social and psychological aspects that are involved in the activity of shopping. For instance, elderly people may like to have a chat with the retailers, but also many people experience shopping as a relaxing and social activity to be enjoyed with friends or family. 
Thus, from a purely functional perspective the future of certain new technologies may look shining, because they promise to fulfil a certain function more effectively. However, because other social and psychological aspects are neglected, future images that are based on strong functional thinking may turn out to be too optimistic about the diffusion, use and expected effects of certain technologies.

A sixth key feature in many speculations is that the process of societal embedding of new technologies is viewed as unproblematic. In the example above on teleworking we mentioned various problematic aspects that turned up in practice and had apparently been underestimated. Similarly, many unforeseen problems turned up when, in the 1980s, many transport firms, co-sponsored by the government, started $\mathrm{R} \& \mathrm{D}$ projects on transport telematic systems. Because future speculations often neglect the adjustment processes that are necessary to reach alignment between so many factors as the characteristics of a technology, user preferences, organisational structures, producer and supplier networks, and government regulations, they often overestimate the speed and impact of developments.

A seventh key feature is that voiced expectations, in particular by promotors of an emerging technology, initially promise high societal gains or advantages, that in later phases appear to be unrealistic and then have to be scaled down and adjusted. Examples of this key feature can be found in Tables 2-4 for expectations concerning respectively the direct impact of ICT on road efficiency, the substitution potential of tele-conferencing on business travel, and the number of tele-workers. To some extent, this key feature can be interpreted as a result of the fourth and sixth key features, that is, initial broad expectations and promises are neglecting the co-evolution of technology and society, and are underestimating the practical difficulties and resulting slowness of processes of societal embedding of technology.

The seven key features discussed above can be translated into possible pitfalls for future expectations. This is done in Table 5.

\section{A complementary explanation: the role of expectations in technological development}

The seven key features in explaining the failure of images of the future can be interpreted as resulting from ignorance and short-sightedness of forecasters or futurists, lacking insights from technology studies and using too simplistic assumptions about the impact of technology. Although this interpretation often has validity, it is, in our view, only part of an explanation for the seventh key feature, that says that initial promises of a technology's impact turn out to be too high and have to be scaled down in later periods. Below, we give a complementary interpretation of this seventh key feature, which focuses on the performative role of expectations and future images in technological developments. That is, future images may be intended as interventions to affect the direction and speed of technological developments.

New technological options often emerge as "hopeful monstrosities" [48]. They are "hopeful" because they have demonstrated that they can fulfil some societal function, but they are "monstrous" because their performance characteristics are low. For 
Table 5

Pitfalls in future explorations of technological developments

\begin{tabular}{|c|c|c|}
\hline Pitfalls & Neglected aspects & Examples \\
\hline $\begin{array}{l}\text { Expectations have cultural biases, } \\
\text { reflecting current beliefs, hopes, } \\
\text { fears }\end{array}$ & $\begin{array}{l}\text { Cultural changes or alternative } \\
\text { directions of technological } \\
\text { development }\end{array}$ & $\begin{array}{l}\text { Centralised steering computer } \\
\text { traffic systems in } 1960 / 70 \text { s. } \\
\text { Decentralised informative } \\
\text { telematic systems from mid- } \\
\text { 1980s on. }\end{array}$ \\
\hline $\begin{array}{l}\text { Focus on current technological } \\
\text { trajectories }\end{array}$ & Alternative technological futures & Same example as above \\
\hline $\begin{array}{l}\text { Potential of new technology is } \\
\text { phrased in terms of substitution } \\
\text { of old technology }\end{array}$ & $\begin{array}{l}\text { Co-existence of old and new } \\
\text { technologies. Generation next to } \\
\text { substitution }\end{array}$ & $\begin{array}{l}\text { Replacement of paper products } \\
\text { by computer systems (paperless } \\
\text { society vs printing office) }\end{array}$ \\
\hline $\begin{array}{l}\text { Pool of existing social practices } \\
\text { is assumed to remain constant in } \\
\text { spite of the introduction of a } \\
\text { new technology }\end{array}$ & $\begin{array}{l}\text { Co-evolution of technology and } \\
\text { society. Generation next to } \\
\text { substitution }\end{array}$ & $\begin{array}{l}\text { Tele-conferencing and business } \\
\text { travels. Tele-working and impact } \\
\text { on both commuting and } \\
\text { recreational traffic subsystems }\end{array}$ \\
\hline Functional thinking & Other social needs & $\begin{array}{l}\text { Tele-shopping and sociable } \\
\text { shopping }\end{array}$ \\
\hline $\begin{array}{l}\text { Overestimation of speed of } \\
\text { societal embedding of new } \\
\text { technology }\end{array}$ & $\begin{array}{l}\text { Practical problems and } \\
\text { adjustment processes }\end{array}$ & $\begin{array}{l}\text { Telematics in traffic and } \\
\text { transport. Tele-working }\end{array}$ \\
\hline $\begin{array}{l}\text { Initial promises in future } \\
\text { expectations are too high and } \\
\text { have to be scaled down in later } \\
\text { periods. }\end{array}$ & $\begin{array}{l}\text { The role of promises in } \\
\text { technological development }\end{array}$ & $\begin{array}{l}\text { Transport telematics and } \\
\text { improvements of road efficiency. } \\
\text { Tele-conferencing and } \\
\text { substitution of business travels. } \\
\text { Growth of tele-working. }\end{array}$ \\
\hline
\end{tabular}

example, when the telephone was invented in 1876, the person on one side of the line had to shout loudly while the person on the other side of the line had to listen carefully. The cars with internal combustion engines in the 1890 s were dangerous and dirty machines that frequently broke down, and performed not much better than alternatives like the electric and steam vehicles. The ENIAC computer, completed in 1946, weighed 30,000 $\mathrm{kg}$ and consisted of 48,000 thousand switches. These switches frequently broke down and had to be replaced [49].

Because of their low performance characteristics, new technological options ("hopeful monstrosities") cannot immediately compete on the market. They first need to be nurtured and further developed. Developers of new technologies, therefore, try to create a "protected space" in which they can improve their technologies, hopefully increasing the performance characteristics. In quasi-evolutionary theories of technological developments these protected spaces are called "niches" [50,51]. A niche consists of a network of actors (e.g. funding organisations, technology developers) that share a belief in the future potential of a new technology and are willing to invest time and money in its further development.

The crucial point in the context of this article is that promises are diffuse scenarios about the potential of future technologies and as such are crucial resources in the 
creation of niches. Van Lente [52] has investigated the role of promises, expectations and diffuse scenarios in technological development both theoretically and empirically. He argues that when a new technological opportunity emerges, its protagonists formulate promises and diffuse scenarios about its future potential in order to convince relevant communities, e.g. policy makers or engineers, to invest in it. Thus a process of political or technological agenda setting takes place. When the broad promises are translated into concrete requirements, money and other resources may become available to establish the above mentioned protected spaces where concrete activities can take place for a certain period of time. Through the concrete development activities people learn about the technological characteristics and potential applications. After some time the outcomes are assessed and new promises and requirements are formulated that are more specific and detailed than the earlier ones. This cycle may be repeated several times. Van Lente [52], therefore, calls this entire process the "promise-requirement cycle". From this perspective, technological development can be understood as consisting of a series of promise-requirement cycles. Fig. 1 schematically visualises this social role of promises and expectations.

The important point for our analysis is that during subsequent cycles a shift occurs from broad, diffuse expectations to future assessments that pay attention to the concrete applications and social practices involved. Put differently, a shift occurs from wide speculations to more practically oriented assessments.

In line with the above perspective on the role of promises and characteristics, we can now interpret the seventh key feature as a basic element in all kinds of new technological developments. The reason that initial promises and expectations are too optimistic is not that forecasters or futurists are ignorant or shortsighted. Instead,

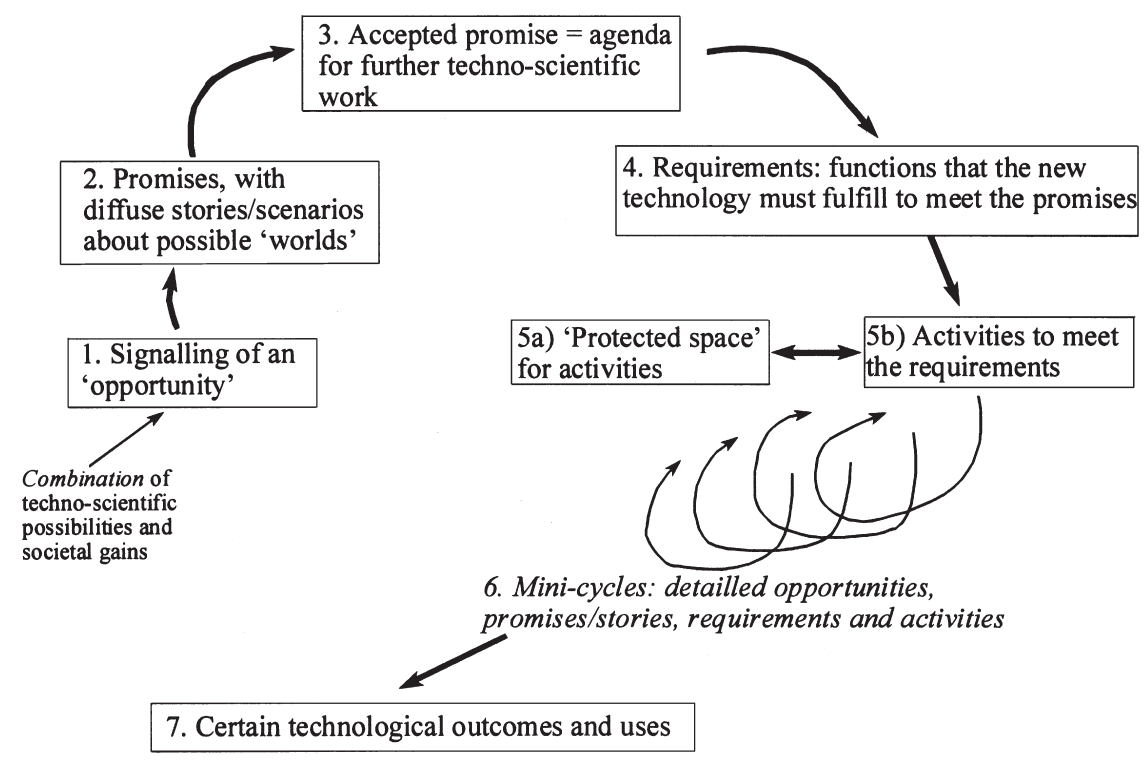

Fig. 1. The social function of promises and expectations in technological developments [53]. 
the promises are strategic resources in promise-requirement cycles. Initial promises are set high in order to attract attention from (financial) sponsors, to stimulate agendasetting processes (both technical and political) and to build "protected spaces". Promises thus play a role in the social processes that are part of technological development. This performative dimension of future images provides a complementary interpretation of the failure of some future speculations. The seventh key feature, therefore, can be explained by the fact that promises and expectations are part of strategic games. Some future speculations do not strive for truth or accuracy, but are meant to influence specific social processes in technological developments.

\section{Concluding remarks}

Many future images do not come true, because they are based on too simplistic conceptualisations of technological development and its impact on society. In particular, the neglect of the dynamic co-evolution of technology and society is often an important cause for this failure. We have specified this general cause into seven key features of the failure of future images, ranging from the neglect of wider cultural changes, to underestimation of practical adjustment processes in the adoption of technology. These key features are accessibly summarised in Table 5 in terms of pitfalls and neglected aspects. Our research also shows the relevance of technology studies for designing new future oriented methodologies, such as the development of sociotechnical scenarios [54].

Insights from technology studies have also been useful in showing that there is a complementary explanation for at least one of the key features of failing technology futures. This explanation focuses on the performative role of promises and expectations in the social process of technological development.

Does the phenomenon revealed by this complementary explanation about future expectations of new technologies constitute a serious problem? The answer is no and yes. No, because advocates of a new technology have to mobilise support and one resource for this is the promises of the new technology. For this mobilising purpose, the advocates cannot do without some societal blinkers. Thus, it cannot be prevented that promises and expectations are part of strategic games. The answer is yes, when policy choices have to be made about which technologies should be supported and when decisions have to be made on investments. Policy makers then should not go along too easily with promises of very high future impacts. Instead, they should have an eye for the pitfalls revealed by the seven key features, summarised in Table 5. Thus, more reflexive decisions about the allocation of resources to new technological developments can be made, that take into account the broad variety of possible societal impacts.

\section{Acknowledgements}

This article is based on research that has been funded by the Dutch Ministry of Transportation as part of the research programme "The impact of the information 
society on traffic and transportation". This programme was conducted in 1997, and consisted of five projects. Geels and Smit were responsible for one project "Future images in the past". This has resulted in two reports [1,2].

\section{References}

[1] Geels FW, Smit WA. Toekomstbeelden in het Verleden: De Invloed van de Informatiemaatschappij op Verkeer en Vervoer. Main report. Rotterdam: Ministry of Transportation Report Series, 1997.

[2] Geels FW, Smit WA. Toekomstbeelden in het Verleden: De Invloed van de Informatiemaatschappij op Verkeer en Vervoer. Background report. Rotterdam: Ministry of Transportation Report Series, 1997.

[3] Fischer CS. America calling: a social history of the telephone to 1940. Berkeley: University of California Press, 1992.

[4] Calder N, editor. The world in 1984; the complete New Scientist series. Harmondsworth: Penguin Books, 1964.

[5] Bournonville L. The customer's ideal computer. In: Calder N, editor. The world in 1984; the complete New Scientist series. Harmondsworth: Penguin Books, 1964:139-42.

[6] Glanville W. Roads and traffic in 1984. In: Calder N, editor. The world in 1984; the complete New Scientist series. Harmondsworth: Penguin Books, 1964:187-9.

[7] Van der Burgt GJ. Toekomstige ontwikkelingen in het wegverkeer. In: Cuperus JLH, editor. Verkeersmiddelen. The Hague: Stichting Toekomstbeeld der Techniek, Koninklijk Instituut van Ingenieurs, 1968:41-54.

[8] Hupkes G et al. Transport in de toekomst: Koorddansen tussen wens en werkelijkheid. Amsterdam: Wetenschappelijke Uitgeverij NV, 1970.

[9] Thoone MGL. Informatiesystemen voor verkeer en vervoer. Informatie en informatiebeleid 1987;5:69-77.

[10] Ministerie van Verkeer en Waterstaat. Telematica, Verkeer en Vervoer. The Hague: SDU-Uitgeverij, 1990.

[11] Elzen B, Hoogma R, Schot J. Mobiliteit met toekomst: Naar een vraaggericht toekomstbeleid. Rotterdam: Ministerie van Verkeer en Waterstaat, Directoraat-Generaal Rijkswaterstaat, Adviesdienst Verkeer en Vervoer, 1996.

[12] Ministerie van Verkeer en Waterstaat. Voortgangsnota Telematica, Verkeer en Vervoer. The Hague: SDU-Uitgeverij, 1993.

[13] Ministerie van Verkeer en Waterstaat. Telematica Verkeer en Vervoer, Eindrapportage 1993-1995. The Hague: Co-rdinatiepunt Telematica, 1996.

[14] Stichting Maatschappij en Onderneming. Verkeerschaos en vervoershonger: Perspectief op mobiliteit, The Hague, 1995.

[15] Barry G. Mass communications in 1984. In: Calder N, editor. The world in 1984; the complete New Scientist series. Harmondsworth: Penguin Books, 1964:157-60.

[16] Pierce JR. Private television instead of travel. In: Calder N, editor. The world in 1984; the complete New Scientist series. Harmondsworth: Penguin Books, 1964:151-3.

[17] Clare JD. Decentralization by telecommunications. In: Calder N, editor. The world in 1984; the complete New Scientist series. Harmondsworth: Penguin Books, 1964:154-6.

[18] Petersen H. Telekommunikation und Verkehr. Internationales Verkehrswesen 1977:224-8.

[19] Goddard JB, Morris D. The communications factor in office location. Progress in planning $1976 ; 6$.

[20] Kraemer KL. Telecommunications/transportation substitution and energy conservation. Telecomm Policy 1982;7:39-59.

[21] European Conference of Ministers of Transport. Transport and telecommunications. Paris: ECMT, 1983.

[22] Henckel D, Nopper E, Rauch N. Informationstechnologie und Stadtentwicklung. Stuttgart etc.: Deutscher Gemeindeverlag, (Schriften des Deutschen Instituts fuer Urbanistik; Bd. 71), 1984. 
[23] Samuel AL. The banishment of paper-work. In: Calder N, editor. The world in 1984; the complete New Scientist series. Harmondsworth: Penguin Books, 1964:142-7.

[24] Naisbitt J. Megatrends, ten new directions transforming our lives. New York: Warner Books, 1982.

[25] Nilles JM, Carlson TR, Gray P, Hanneman GJ. The telecommunications-transportation tradeoff: options for tomorrow. New York; London: John Wiley and Sons, 1976.

[26] Stanford Research Institute. Technology assessment of telecommunications-transportation interactions. Vols. I, II, III, Menlo Park, California, 1977.

[27] Toffler A. The third wave. New York: Bantam Books, 1980.

[28] Nilles JM. Managing teleworking: A project in the information technology program. Los Angeles: Center for Futures Research, 1984.

[29] Electronic Services Unlimited. Telecommuting Research Program. New York: ESU, 1984.

[30] Telematics Research Centre. Telewerk, werkbaar of werkzaam? Twee visies op de toekomst. Enschede: Telematics Research Centre Publications, 1994.

[31] Nilles JM. Teleworking from home. In: Forester T, editor. The information technology revolution. Oxford: Basil Blackwell Ltd, 1985:202-8.

[32] Miles I, et al. IT Futures surveyed, Brighton: Innovation Research Group and Science Policy Research Unit, working paper, 1985.

[33] Kok A., Mante E, Melieste J. Telewerk, de werkvorm van de toekomst?. Studieblad PTT Telecom, May, 1993:268-93.

[34] Weijers T, Weijers S. Telework: Een overzichtsstudie naar recente trends en toekomstperspectieven. The Hague: Ministerie van Sociale Zaken en Werkgelegenheid, 1986.

[35] Meijer RAM, Wijers TCM, Spoelman EJ, Rip A. Telewerk blijft maatwerk: De invoering van telewerk op grote schaal: kosten en baten en de invoeringsstrategie, Apeldoorn: TNO-Beleidsstudies, Studiecentrum voor Technologie en Beleid TNO, 1992.

[36] Forester T. The myth of the electronic cottage. Futures 1988;6:227-40.

[37] Fokkema J. Telewerken dichterbij? Een onderzoek naar de haalbaarheid van werken met telematica in de woonomgeving. Amersfoort: Stichting Werkgroep '2duizend, 1990.

[38] Forester T. Megatrends or megamistakes? whatever happened to the information society? The Information Soc 1992;8:133-46.

[39] Salomon I. Telecommunications and travel: Substitution or modified mobility?. J. Transp. Economics and Policy 1985;19:219-35.

[40] Salomon I. Telecommunications and travel relationships: a review. Transportation Res 1986;20(3):223-38.

[41] Nijkamp P, Salomon I. Telecommunication and the tyranny of space. In: Orishima I, Hewings GJD, Nijkamp P, editors. Information technology: social and spatial perspectives. Proceedings of an international conference on information technology and its impact on the urban-environmental system, Held at Toyohashi University of Japan, 1986, 1987:91-104.

[42] Wack P. Scenarios: uncharted waters ahead. Harvard Business Review. September-October 1985:73-89.

[43] Wack P. Scenarios: Shooting the rapids. Harvard Business Review. November-December 1985:139-50.

[44] Flink JJ. The automobile age. Cambridge, Mass: MIT Press, 1988.

[45] Bassala G. The evolution of technology. Cambridge, New York: Cambridge University Press, 1988.

[46] Rip A. Introduction of new technology: making use of recent insights from sociology and economics of technology. Tech Analy Strat Mgmt 1995;7:417-31.

[47] Green K. Creating demand for biotechnology: Shaping technologies and markets. In: Coombs R, Saviotti P, Walsh V, editors. Technological change and company strategies: Economic and sociological perspectives. San Diego: Academic Press Limited, 1992:164-84.

[48] Mokyr J. The lever of riches. New York: Oxford University Press, 1990.

[49] Nijholt A, Van den Ende J. Geschiedenis van de rekenkunst, van kerfstok tot computer. Schoonhoven: Academic Service, 1994.

[50] Schot J. Maatschappelijke sturing van technische ontwikkeling: Constructief Technology Assessment als hedendaags Luddisme. PhD thesis, Enschede: University of Twente 1991.

[51] Weber M, Hoogma R. Beyond national and technological styles of innovation diffusion: a dynamic 
perspective on cases from energy and transportation sectors. Tech Analy Strat Mgmt 1998;10(4):545-66.

[52] Van Lente H. Promising technology: The dynamics of expectations in technological developments. PhD thesis, Delft: Eburon, Enschede: University of Twente 1993.

[53] Van Lente H, Rip A. Expectations in technological developments: an example of prospective structures to be filled in with agency. In: Disco C, Van der Meulen BJR, editors. Getting new technologies together. Berlin: Walter de Gruyter, 1998:195-220.

[54] Focused Study on the Social Shaping of Technology. Commissioned Report for the European Commission. 2000 (in press). In: Williams R, editor. Concepts, spaces and tools: Recent developments in social shaping research. Commissioned Report for the European Commission. 2000. 